\title{
HOMO SACER SEBAGAI FIGUR POLITIS DAN KAITANNYA DENGAN DUNIA PENDIDIKAN TINGGI
}

\author{
Ferdinand Indrajaya \\ Jurusan Desain Komunikasi Visual, Fakultas Komunikasi dan Multimedia, Bina Nusantara University \\ Jln. K.H. Syahdan No. 9, Palmerah, Jakarta Barat 11480 \\ ferdinand_indrajaya@yahoo.ca
}

\begin{abstract}
Article is an outcome from writer's reflection from his reading on Homo Sacer, Sovereign Power and Bare Life, a book by Giorgio Agamben, an Italian $20^{\text {th }}$ century philosopher. The reading concerns with the three chapters which are Homo Sacer, The Ambivalence of The Sacred, and The Sacred Life, and also the preface of chapters. Generally, this article proposes two main things. First, Agamben's description on Western modern political practice, developed from the Greek until today. Second, writer's reflection on educational system in Indonesia, especially the higher education level in nowadays, through Agamben's perspective. Structurally, article is divided into three parts. First, the Preface, is a general view to Agamben's political thought which will stand as a background to the second part from this article, Homo Sacer. On the third part, Education as Bare Life, is writer's reflection on higher education system in Indonesia borrowing the political perspectives from Agamben.
\end{abstract}

Keywords: Homo Sacer, state of sovereign, the political, industry, education

\begin{abstract}
ABSTRAK
Artikel merupakan hasil refleksi penulis setelah membaca buku teks yang ditulis oleh Giorgio Agamben, seorang filosof abad 20 asal Italia, yang berjudul Homo Sacer, Sovereign Power and Bare Life. Bahasan bertolak dari tiga teks rujukan, yaitu Homo Sacer, The Ambivalence of The Sacred, dan Sacred Life, juga bagian prakata dalam teks rujukan, Artikel membahas dua hal, pertama adalah Homo Sacer yang diutarakan Agamben sebagai figur arkaik, merupakan manifestasi dari syarat kemungkinan bagi kedaulatan, dan figur politis. Kedua, refleksi penulis tentang dunia pendidikan tinggi di Indonesia secara umum melalui kaca mata Agamben. Artikel menyampaikan Homo Sacer dalam tiga bagian. Bagian pertama, yaitu Pendahuluan, merupakan garis besar pemikiran Agamben, yang akan melatari bagian kedua, yaitu tentang Homo Sacer itu sendiri. Bagian ketiga, yaitu Dunia Pendidikan sebagai Bare Life, adalah refleksi penulis yang mengaitkan pandangan Agamben dengan dunia pendidikan tinggi saat ini.
\end{abstract}

Kata kunci: Homo Sacer, kedaulatan, yang politis, industri, pendidikan 


\section{PENDAHULUAN}

Deskripsi Agamben mengenai praktik politik yang berkembang di Barat, khususnya dalam kerangka pemikiran modern, sedikit banyak juga merupakan kritik terhadapnya. Pandangan politik ala Barat yang menjadi titik tolak pemikirannya adalah semenjak Plato (Agamben, 1998), yang selanjutnya dikembangkan oleh Aristoteles, dan yang memuncak pada modernisme. Pemikiran Agamben tentang praktik politik modern yang hadir di dunia Barat yang sekaligus kritik terhadapnya, tidak terlepas dari pemikiran kontemporer Michel Foucault tentang praktik politik dalam modernism, seperti tertulis, “..., man remained what he was for Aristotle: a living animal with the additional capacity for political existence; modern man is animal whose politics calls his existence as a living being into question" (Agamben, 1998)

Menurut Foucault, politik sebagai bagian dari ilmu sosial yang berkembang melalui modernisme telah menempatkan manusia dalam tanda tanya. Dalam praktik politik modern, manusia adalah binatang yang dipertanyakan adanya, mahluk hidup yang selalu dipertanyakan eksistensinya. Manusia, yang bagi Aristoteles adalah mahluk hidup dengan kapasitas untuk berpolitik telah mengembangkan suatu sistem politik yang berangsur-angsur malahan mempertanyakan eksistensinya atau adanya sebagai manusia. Dengan kalimat yang berbeda, bagi Foucault, manusia modern telah membinatangi dirinya sendiri dengan teknik politik yang dikembangkan sendiri. Ilmu pengetahuan sosial melalui modernisme, dalam hal ini, menghadirkan suatu ambivalensi, sebuah pisau bermata dua. Di satu sisi, tidak dapat dipungkiri ia memberi sumbangsih bagi kehidupan berpolitik (berupa konsep tentang manusia dan tata cara hidupnya dalam berkewarganegaraan). Namun, di sisi lain juga lahir peperangan dan pembunuhan; ia juga yang mengizinkan praktik pemusnahan umat manusia dalam Holocaust (Agamben, 1998), yang merupakan sebuah tragedi kelam dalam sejarah umat manusia.

Politik, sebagai bagian dari ilmu sosial modern, telah membuat pembedaan antara hidup yang layak hidup dengan hidup yang dapat dimusnahkan (ingat peristiwa Holocaust). Melalui pandangan Foucault, dan lewat pembacaan Agamben, hidup yang layak hidup adalah hidup yang telah disiplinkan, docile body (istilah khas Foucault). Istilah docile body (tubuh penurut) dari Foucault ini berkaitan dengan pandangan Foucault tentang kuasa. Bagi Foucault, kuasa bukanlah bersifat kebendaan yang dapat dimiliki, namun strategi. Maksudnya, kuasa dipraktikkan dalam suatu ruang lingkup tempat setidaknya lebih dari satu posisi strategis yang berkaitan satu sama lain; ada yang menguasai dan ada yang dikuasai (Bertens, 2006), tidak mungkin hanya salah satu saja, berdiri sendiri secara penuh diri. Kuasa sebagai strategi tidak bekerja melalui melulu penindasan, namun dapat juga mengalir melalui suatu tindak normalisasi (pendisiplinan) lewat regulasi (Bertens, 2006).

Salah satu bidang normalisasi atau pendisiplinan ini adalah tubuh dari yang bersifat alamiah atau fisik (misalnya: senam dan berolah-raga sebagai tindakan penjagaan tubuh untuk tetap sehat dan jauh dari penyakit) sampai kepada yang berkaitan dengan norma / penilaian dalam berkehidupan sosial (misalnya: tubuh harus dirawat dengan baik kalau mau dianggap sebagai perwakilan dari gaya hidup tertentu dan dipandang normal oleh kelompok masyarakat tertentu). Dengan demikian, kata 'body' dalam docile body, bukan hanya merujuk pada tubuh biologis saja, namun dapat juga merujuk secara metaforis, simbolisasi akan suatu cara hidup itu tertentu. Hidup yang sesuai dengan konsep politik dari suatu posisi kedaulatan, adalah hidup yang normal, berharga untuk dibiarkan hidup. Kata 'sesuai' bermaksud menunjukkan suatu bentuk kehidupan yang telah terdisiplinkan, yang telah menjadi docile body. Bukan hanya itu saja, namun hal ini mengimplikasikan bahwa bentuk hidup yang docile ini akan mendapatkan perlindungan sebagai, misalnya warga negara, dalam suatu sistem politik pemerintahan. Sedangkan yang bukan docile body, atau tidak terdisiplinkan oleh suatu kedaulatan, bukan hidup yang layak dipertahankan atau mendapatkan perlindungan sebagai warga negara dalam suatu sistem pemerintahan. Lebih jauh lagi, dari pandangan Foucault, Agamben mengembangkan pandangannya bahwa bentuk kehidupan yang tidak docile ini pun tidak lepas dari peran kedaulatan itu sendiri, dengan bertolak dari perbedaan antara bahasa (logos) dengan suara (phone). 


\section{PEMBAHASAN}

Bagi Agamben, yang menjadi fondasi atau yang fundamental untuk paradigma politik modern di Barat lahir dari pembedaan antara suara (phone) dan bahasa (logos), antara zoe dan bios (Agamben, 1998), dan yang berujung pada pengasingan (ekslusi) dan penyertaan (inklusi), serta tegangan dari oposisi tersebut. Deskripsi akan hal ini tidak lepas dari pembacaan titik tolak Agamben sendiri, secara umum, yaitu zaman antik Yunani, dan secara lebih spesifik pandangan Aristoteles tentang hidup yang baik; dimana 'baik' disini merujuk pada suatu bentuk hidup rasional yang berketatanan dalam polis, seperti dikatakan, "Born with regard to life, but existing essentially with regard to the good life”(Agamben, 1998)

Artinya, Lahir dengan kapasitas / kemampuan untuk hidup, namun secara kodrati mengada dengan kapasitas (tambahan, bukan hanya untuk sekedar hidup ) untuk hidup yang baik. Lagi, ada kesepakatan dengan Foucault (Agamben, 1998) tentang eksistensi manusia dalam politik, Agamben melihat ada yang problematis dengan pandangan dari Aristoteles tersebut dan hal ini terimplikasi pada praktik politik modern di Barat. Yang problematis adalah kata 'with regard' dalam 'with regard to the good life'. Bagaimana hal ini bermasalah? 'With regard to the good life' bukan hanya dapat dibaca sebagai implikasi dari sebuah kelahiran, namun juga dapat dibaca sebagai penyertaan (inclusion) sekaligus pengasingan (exclusion) zoe ke dalam bios, juga terhadap hidup yang alami (bare life) ke dalam hidup yang politis (political life). Dengan demikian, bare life, ada untuk ditiadakan dalam political life.

Menurut Agamben, implikasi ini muncul tidak lepas dari suatu narasi metafisis antropologis tentang ke-apa-an manusia yang berlaku sejak zaman Aristoteles. Manusia berbeda dengan mahluk hidup lain karena ia memiliki 'kapasitas tambahan' untuk berbahasa dan mencapai hidup yang 'baik'. Suatu tatanan polis yang sesuai dapat dicapai karena adanya transisi suara (phone), pada zoe (bare life), menuju kepada bahasa (logos), pada bios (the good life, the political life). Selain itu, dari bentuk kehidupan layaknya binatang menuju ke spesifik manusia, lebih spesifik lagi bukan hanya sebagai manusia, namun manusia sebagai mahluk hidup dengan cara hidup tertentu.

Logos yang hadir pada bios dimiliki sebagai akibat dari meninggalkan sekaligus pembisuan phone (Agamben, 1998). Suara dilupakan sekali gus ada di dalam bahasa itu sendiri. Setia dengan pandangan ini, praktik politik modern di Barat adalah suatu peredaman suara ke dalam bahasa itu sendiri, barelife ke dalam political life; suatu proses bios-nisasi zoe. Dengan kalimat yang berbeda dapat dikatakan bahwa praktik politik modern di Barat adalah sebuah tindakan politisasi terhadap hidup yang telanjang (bare life) itu sendiri (Agamben, 1998).

Politik hadir karena manusia, sebagai mahluk hidup yang berbahasa, memisahkan dan melawankan diri dengan bare life-nya sendiri, namun tidak sungguh-sungguh bebas darinya. Menyinggung kembali istilah docile body dari Foucault, zoe adalah tubuh yang harus didisiplinkan, menjadi tubuh yang docile (penurut). Zoe ada di dalam bios, dibisukan dan hadir dalam posisi yang subordinat. Agamben melihat bahwa yang politis hadir dalam sebuah status pengecualian (state of exception) yang terjadi dalam tegangan zoe-bios, eksklusi-inklusi. Yang politis bukan hanya hadir melalui pertentangan hubungan kawan dan lawan dalam sebuah status keadaan darurat (state of emergency), sebuah pandangan politik dari Carl Schmitt (Agamben, 1998).

\section{Homo Sacer}

Figur yang dari sudut pandang Agamben dirasa niscaya memegang peranan penting dalam praktik politik modern di Barat adalah homo sacer (manusia sakral), sebagai figur cerminan/ manifestasi dari bare life itu sendiri. Dalam sejarahnya, figur ini sempat disebut oleh oleh Pompeius 
Festus, seorang ahli tata bahasa (grammarian) di zaman kekuasaan Romawi abad kedua Masehi, dalam sebuah risalah yang ditulis dan diberi judul On The Significance of Words berikut.

"The sacred man is the one whom the people have judged on account of a crime. It is not permitted to sacrifice this man, yet he who kills him will not be condemned for homicide; in the first tribunian law, in fact, it is noted that "if someone kills the one who is sacred according to the plebiscite, it will not be considered homicide." This is why it is customary for a bad or impure man to be called sacred." (Agamben, 1998)

Homo sacer, menurut deskripsi Festus di atas, adalah " the unpunishability of his killing and the ban of his sacrifice" (Agamben, 1998). Manusia yang boleh dibunuh namun bukan dalam bentuk pengorbanan, manusia dalam status pengecualian. Manusia yang seperti apa yang dianggap sebagai yang mewakili figur homo sacer / manusia sakral ini di zaman ini? Agamben menunjuk beberapa figur manifestasi, dalam konteks kehidupan modern, sebagai contoh: orang yang memiliki penyakit mental/ kejiwaan, para pengungsi (refugees), orang yang dalam keadaan koma, dan lain sebagainya yang berada dalam kondisi antara zoe dan bios, phone dan logos, bare life dan political life. Maksudnya, yang secara figur, masih dapat dicap sebagai manusia, namun tidak memiliki kapasitas untuk berfungsi sebagai manusia yang sesuai dengan tuntutan suatu kelompok masyarakat. Figur bare life yang 'tidak sampai' kepada the good / political life. Dalam hal ini homo sacer menjadi figur dari yang politis, yang selalu berada dalam tegangan zoe-bios, bare life-political life.

Lalu bagaimana dengan kalimat 'the ban of his sacrifice'? Apa yang dimaksud dengan terhadapnya ia tidak boleh dibunuh dalam bentuk pengorbanan? Alasannya cukup sederhana dan cenderung sangat praktis dan pragmatis, yaitu, "what is sacer is already possessed by the gods and is originally and in a very special way possessed by the gods of the underworld, and so there is no need for it to become so through a new action" (Agamben, 1998)

Ketika seseorang sudah sedemikian dekatnya dengan dunia para dewa, sebuah tindakan baru, yakni pengorbanan, tidak lagi diperlukan. Seseorang yang sedang dalam keadaan koma, misalnya, ada dalam kondisi hidup dan mati, iIa boleh saja 'dimatikan', namun tidak direpotkan dengan 'cara mematikan'. Ia tidak perlu ritual tertentu, toh adanya sebagai manusia sudah tidak utuh lagi dan sudah tidak memiliki kapasitas lebih sebagai suatu bentuk kehidupan. Ia tidak lebih dari hanya sekedar hidup biologis saja. Ia hanya ada di tataran zoe, namun tidak akan sampai ke bios dan bila proses bios-nisasi terhadap zoe tidak berhasil, ia boleh ditiadakan. Mirip halnya bila kita memakai contoh para pengungsi (refugee), mereka berada dalam kondisi beridentitas (kewarganegaraan tertentu) sekaligus tidak beridentitas (misalnya, meninggalkan negaranya karena perang dan sebab lain sebagainya). Homo sacer adalah sebuah figur yang otonom, makna keberadaannya melampaui norma moral yang ada dan hukum yang berlaku (Agamben, 1998). Ilmu sosial yang ada, bagi Agamben, ialah ketika harus berhadapan dengan tegangan antara norma moral dan hukum yang berlaku dalam suatu kelompok masyarakat pun mengalami kesulitan atau setidaknya sulit untuk dapat menjelaskan fenomena homo sacer ini secara jernih dan terpilah-pilah (Agamben, 1998); tidak dapat melampauinya. Terhadapnya, ambivalensi akan selalu muncul; ada sekaligus tidak ada. Ada / hadir dalam kehidupan melampaui zoe, namun tidak ada dalam kerangka hidup yang bios.

Lalu bagaimana hubungan antara homo sacer dengan suatu bentuk hidup yang politis itu sendiri (the political life)? Dalam hal ini adalah pihak yang mendapat status berdaulat (state of sovereign)? Apakah keberadaan homo sacer sama sekali tidak mempengaruhi kedaulatan dalam hidup berpolitik? Dari sudut pandang Agamben, bare life justru diproduksi oleh kedaulatan itu sendiri, malahan produksi akan bare life merupakan kegiatan yang asli dari kedaulatan (Agamben, 1998).

Hal ini menjadi konsisten dengan apa yang dipaparkan pada bagian pendahuluan artikel ini, yaitu tentang bagaimana logos 'menguasai' phone, bahasa menguasai suara. Kedaulatan bukan hanya mengobyektifikasi homo sacer namun keberadaannya, eksistensinya, tidak dapat dilepaskan 
dari figur homo sacer itu sendiri. Keputusan apa pun yang diambil oleh kedaulatan terhadap homo sacer adalah eksistensi dari kedaulatan itu sendiri. Bagaimana kedaulatan bersikap terhadap yang diposisikan sebagai pengecualian, memperlihatkan seberapa berdaulat kedaulatan tersebut.

Dalam pandangan Agamben ini, homo sacer hadir sebagai figur dari suatu status / kondisi pengecualian (state of exception) yang merupakan syarat kemungkinan bagi praktek politik itu sendiri. Ini yang dimaksud dengan homo sacer sebagai figur dari yang politis. Yang politis adalah kondisi yang memungkinkan kebijakan politik tertentu, sebagai regulasi hadir melegitimasi dirinya, sebuah kondisi yang selalu sebelum.

\section{Dunia Pendidikan sebagai Bare Life}

Bagian akhir artikel membahas hubungan zoe dan bios dari sudut pandang Agamben dalam konteks praktik politik di Barat. Hal ini menjadi kacamata dalam merefleksikan kondisi dunia pendidikan tinggi yang sampai saat ini berlaku di Indonesia. Bagaimana pemikiran Agamben dalam konteks politik dapat membantu menerangi/ mengangkat beberapa masalah yang muncul dalam konteks pendidikan tinggi dan universitas di Indonesia pada umumnya sampai pada saat ini. Sebagai sedikit latar mengenai keterkaitan deskripsi Agamben tentang Homo Sacer dengan apa yang marak menjadi kecenderungan dunia pendidikan tinggi saat ini, penulis bertolak terlebih dahulu dari sebuah perbedaan antara yang seharusnya dengan yang ada.

Keberadaan dunia pendidikan seharusnya ada di ranah publik dan adanya tidak lepas dari apa yang menjadi kepentingan publik, bukan sebaliknya di ranah privat dan mewakili kepentingan privat tertentu. Pernyataan tentang yang seharusnya terkait dengan dunia pendidikan tinggi ini tidak lepas dan konsisten dengan pemahaman awal (berbenih di zaman Yunani antik sampai puncaknya pada modernisme yang berkembang di Barat) mengenai universitas itu sendiri.

Universitas, sebagai insitusi pendidikan tinggi, pertama-tama berurusan dengan pencarian akan hal yang bernilai universal (Watson, 2005), bukan yang partikular; yang lebih terkait dengan hal yang sifatnya publik dari pada yang bersifat privat. Misalnya, ilmu Ekonomi dalam sebuah fakultas akan mencari aturan (nomos) yang terkait dengan kestabilan suatu tatanan 'rumah tangga' (oikos) dan bagaimana hal ini memiliki dampak bagi sekitar. Yang dimaksud 'rumah tangga' di sini dapat diterjemahkan sebagai, misalnya, negara yang membicarakan aturan / kebijakan yang terkait dengan stabilnya tatanan 'rumah tangga' suatu negara, bagaimana hal ini mempengaruhi kehidupan warga negara dan bagaimana kebijakan tersebut memiliki dampak luas terhadap keberadaannya di antara negara-negara lain.

Ilmu ekonomi bukan berurusan dengan hal partikular seperti bagaimana tips dan trik berdagang melalui internet, namun lebih luas dan universal dari pada itu. Berdagang melalui internet hanyalah salah satu cara (partikular) untuk mempertahankan kestabilan ekonomi rumah tangga atau pendapatan seseorang, namun bukan ilmu ekonomi itu sendiri secara keseluruhan. Berlanjut dari pemahaman tersebut maka menjadi konsisten juga kalau dikatakan bahwa tugas universitas adalah menjadikan manusia lebih manusia (Drost, 1998). Manusia yang semakin mencari dan menghayati nilai universal dari kemanusiaan itu sendiri, bukan manusia yang menciutkan keberadaannya dalam nilai yang partikular dan pada akhirnya memiskinkan nilai kemanusiaan itu sendiri. Inilah yang seharusnya terkait dengan keberadaan universitas.

Mungkin masih ada beberapa institusi pendidikan tinggi di Indonesia sekarang ini yang masih mempertimbangkan atau menggelisahkan universitas versi 'yang seharusnya' dari paragraf di atas. Namun, kebanyakan, mungkin tidak. Yang ada sekarang adalah versi kebalikannya. Hal yang terkait dengan universitas, keberadaan dan tujuan telah bergeser dari ranah publik menuju ranah privat. Inilah yang ada kebanyakan sekarang, dan yang ada ini pada akhirnya menentukan yang seharusnya 
ada. Karena kebanyakan sekarang universitas tidak lagi ada di ranah publik dan dirasuki ranah privat maka inilah yang seharusnya ada, setidaknya inilah anggapannya bagi sebagian besar anggota masyarakat. Yang terjadi adalah reduksi fakta menjadi sama dengan nilai, kuantitas mutlak menentukan kualitas, yang banyak adalah mutlak yang baik. Yang banyak adalah privatisasi dunia industri terhadap universitas maka inilah yang baik dan menjadi yang seharusnya ada.

Kondisi ini menjadi bertolak belakang dengan tujuan awal universitas itu sendiri. Manusia tidak lagi lagi dilihat sebagai manusia sepenuhnya, namun manusia sejauh ia bermental operasional bagi dunia industri. Manusia adalah manusia sejauh berkesesuaian dengan pandangan dan kepentingan industri, manusia yang dilihat hanya dari tindak operasionalnya saja. Lalu bagaimana kondisi ini berkaitan dengan pandangan Agamben? Privatisasi dari yang awalnya publik adalah tidak berbeda dengan biosnisasi terhadap zoe/ bare life. Kepentingan privat diwakili oleh industri sebagai kedaulatan (state of sovereign), sedangkan ranah publik diwakili oleh dunia pendidikan, yang dari kaca mata kedaulatan, menjadi zoe / bare life; yang harus diindustrialisasi. Homo Sacer sebagai figur dari yang politis dalam konteks politik pandangan Agamben dicerminkan oleh mahasiswa dan para lulusan dari universitas. Bagaimana mereka ini adalah manifestasi Homo Sacer? Manusia selama berkesesuaian dengan kepentingan industri, bukan manusia dalam keutuhannya. Manusia yang menjadi manusia lewat tindak operasionalnya saja, yang hanya mewakili kepentingan pragmatis dari industri, tidak dapat lebih dari itu; manusia yang bukan manusia.

Lalu apa implikasinya dari cara berada semacam ini? Bila mewakili kepentingan industri maka seharusnya memberi keuntungan dan kemajuan bagi dunia industri itu sendiri. Namun, di sisi lain, yang ada adalah sebaliknya, industri malahan merencanakan pembunuhan dirinya sendiri. Bagaimana hal ini dijelaskan? Contohnya adalah keilmuan DKV yang sedang meledak kuota peminatnya pada saat ini. Hampir semua universitas privat di Indonesia, khususnya di Jakarta, bereuphoria membuka jurusan ini. Dari setiap jurusan menjanjikan akan melahirkan desainer yang siap pakai, atau bekerja di dunia industri. Dengan demikian, banyak hal yang ada di industri dijadikan titik tolak dan rujukan kurikulum. Hal ini dapat dilihat dengan semakin berkurangnya mata kuliah teoritis, misalnya Estetika, Sejarah, Semiotika, dlsb. yang menuntut kemampuan berpikir abstrak, kritis, dan reflektif untuk digantikan oleh mata kuliah yang murni pragmatis. Mengapa? Jawabnya adalah sederhana, yaitu karena tidak ada sumbangsih nilai pragmatis, sembari melupakan / menyadari bahwa berpikir reflektif adalah juga bagian dari praktik tindakan. Berpikir adalah tindakan, bukan hanya dapat menggambar, dapat mengoperasikan komputer dengan perangkat lunak tertentu, atau segala hal yang sifatnya operasional saja yang dianggap tindakan atau ada gunanya.

\section{PENUTUP}

Benar dan berguna (pragmatis) adalah benar dan berguna dari kaca mata industri bukan dari kaca mata perkembangan keilmuan dalam lingkup universitas itu sendiri. Akhirnya, banyak lulusan dan mahasiswa dapat mengoperasikan perangkat lunak dengan baik, namun sedikit yang mampu berpikir kritis, mendahaga akan ide berbeda, peka akan hal yang berkaitan dengan seni, dlsb. Sedangkan kenyataannya lulusan selain mampu mengoperasikan perangkat lunak tertentu, juga dibutuhkan untuk menjadi seorang desainer, dan dibutuhkan juga oleh dunia industri yang berujung pada perkembangan mereka. Jurusan DKV pada akhirnya menghasilkan desainer yang bukan desainer. Seseorang adalah desainer dalam artian lulus dari jurusan desain sebuah universitas ternama, namun cara pikir dan bertindaknya tidak lebih dari seorang operator saja. Dalam bahasa Agamben, ini sama saja dengan manusia yang bukan manusia, Homo Sacer. Lebih jauh lagi, bila hal ini tidak hanya terjadi dalam bidang keilmuan DKV, namun juga terjadi di bidang keilmuan lain maka pertanyaan selanjutnya adalah, apakah memang masih dibutuhkan label universitas apabila ia tidak lain adalah kosmetik bagi industri? Jangan-jangan harus diganti menjadi partikularitas atau multi-versitas. Apakah 
masih harus mengecap pendidikan tinggi dalam sebuah institusi formal bernama universitas bila hanya untuk menciptakan manusia operasional saja? Apakah masih pantas industri mengeluhkan kinerja lulusan 'operasional' universitas yang merupakan akibat dari proses industrialisasi yang dilakukan pelaku industri itu sendiri? Bila dalam konteks politik dari pandangan Agamben, biosnisasi zoe / bare-life adalah suatu kegiatan asali dari kedaulatan dan yang memungkinkan penentuan posisi kedaulatan itu sendiri, maka dalam konteks pendidikan posisi kedaulatan yang termanifestasi sebagai dunia industri pun sudah tertentukan, yakni sebagai pengeluh yang berdaulat akan 'produk'nya sendiri.

Akhirnya, disebutkan bahwa bagian akhir artikel ini bukan semata-mata ingin memojokkan atau menganggap rendah posisi dunia industri. Biar bagaimana pun, kemawasan akan apa yang terjadi di dunia industri harus ada, toh dunia tersebut adalah salah satu bagian dari dunia kehidupan kita sebagai manusia. Namun, juga harus ada kesadaran bahwa dunia industri adalah bukan satu-satunya dunia yang harus dirujuk, apalagi menjadi fondasi bagi universitas secara khusus dan dunia pendidikan secara umum. Bila kesadaran akan hal ini tidak digelisahi dan proses industrialisasi dunia pendidikan tetap dinyamankan maka siapkan banyak tenaga untuk berkeluh kesah atas apa yang dihasilkan dan yang akan dihadapi. Namun, bila malahan senyum dan pesta pora yang ada sebagai pengganti keluh kesah, maka, selamat menghidupi dunia kehidupan dalam solipsisme-nya yang nihilistik.

\section{DAFTAR PUSTAKA}

Agamben, G. (1998). Homo Sacer, Sovereign Power and Bare Life (translated by Daniel HellerRoazen) USA: Stanford University Press.

Bertens, K. (2006). Filsafat Barat Kontemporer Prancis. Jakarta: Gramedia Pustaka Utama.

Drost, J.I.G.M. (1998). Sekolah: Mengajar Atau Mendidik?, Yogyakarta: Kanisius.

Watson, P. (2005). Ideas, A History of Thought and Invention, from Fire to Freud, New York: Harper Collins. 